\title{
Colonic Mantle Cell Lymphoma with Multiple Lymphomatous Polyposis
}

\author{
Rama Nassri $^{a} \quad$ Ammar Nassri $^{b} \quad$ Ahmad Alkhasawneh $^{c}$ Bruno de Souza Ribeiro ${ }^{b}$ \\ Ron Schey ${ }^{b}$
}

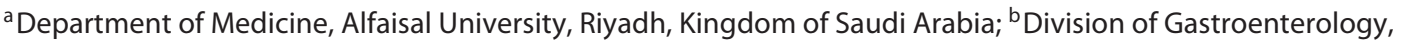
Department of Medicine, University of Florida at Jacksonville, Jacksonville, FL, USA; ' $D$ epartment of Pathology, University of Florida at Jacksonville, Jacksonville, FL, USA

Keywords

Cancer $\cdot$ Colon $\cdot$ Mantle cell lymphoma

\section{Linfoma de células do manto do colon com polipose linfomatosa múltipla}

\section{Palavras Chave}

Cancro $\cdot$ Colon $\cdot$ Linfoma do manto

A 64-year-old white male with a past medical history of coronary artery disease, hypertension, and diabetes presented for a screening colonoscopy. He had no complaints of hematochezia, nor of any fevers, fatigue, night sweats, or chills. A colonoscopy was performed and revealed diffuse, innumerable sessile sub-centimeter polyps throughout the colon (Fig. 1), as well as a fungating, ulcerated mass arising from the ileocecal valve (Fig. 2). The mass was biopsied and representative samples of the polyps were resected. Pathology revealed mantle cell lymphoma, with the neoplastic lymphocytes staining for CD20 and cyclin D1, but negative for CD3 (Fig. 3, 4). Computed to-

\section{KARGER}

E-Mail karger@karger.com www.karger.com/pjg
(C) 2020 Sociedade Portuguesa de Gastrenterologia Published by S. Karger AG, Basel

Karcer

Open access

This article is licensed under the Creative Commons AttributionNonCommercial-NoDerivatives 4.0 International License (CC BYNC-ND) (http://www.karger.com/Services/OpenAccessLicense). Usage and distribution for commercial purposes as well as any distribution of modified material requires written permission. mography revealed extensive mesenteric and retroperitoneal lymphadenopathy, as well as prominent carinal and hilar nodes. Flow cytometry showed monoclonal CD5positive $\mathrm{B}$ cells, and a bone marrow biopsy revealed 40 $50 \%$ involvement of the bone marrow by mantle cell lymphoma. A PET scan was performed, and revealed extensive FDG-avid retroperitoneal, mesenteric, iliac, inguinal, and bilateral axillary lymphadenopathy as well as an FDGavid cecal mass. The patient was diagnosed with stage IV mantle cell lymphoma, had a Port-a-Cath placed, and was initiated on rituximab and bendamustine given his comorbidities and poor functional status.

Mantle cell lymphomas involving the gastrointestinal tract are rare, accounting for 4-9\% of all gastrointestinal B-cell lymphomas [1]. A modified Ann Arbor classification is used for anatomic description of disease extent [2], although functional status and risk stratification using scores, such as the Mantle Cell International Prognostic Index (MIPI), also play a large role in treatment. Multiple lymphomatous polyposis (MLP) is an uncommon type of primary gastrointestinal lymphoma, presenting as multiple lymphomatous polyps throughout the gastrointestinal tract. Although MLP is most commonly seen with mantle cell lymphoma, it has also been 


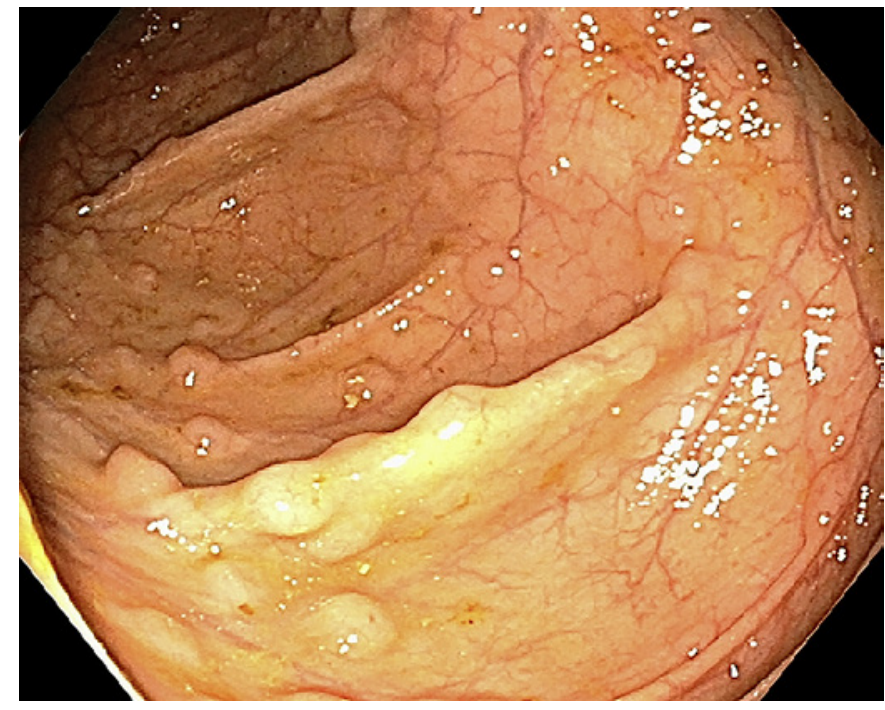

Fig. 1. Diffuse polyps throughout the entire colon consistent with MLP.
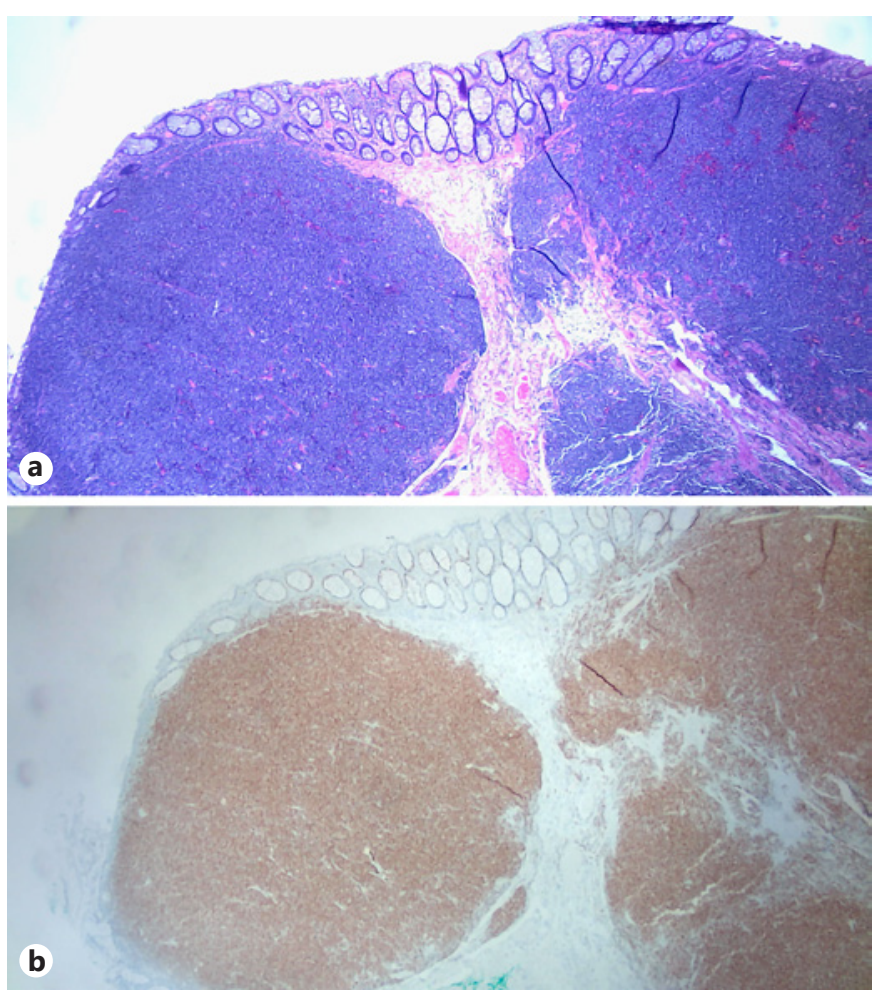

Fig. 3. Mantle cell lymphoma of the colon. a Colon mucosa and submucosa with infiltration by neoplastic lymphocytes (H\&E stain, $25 \times$ ). b The neoplastic lymphocytes are immunoreactive for cyclin D1, which supports the diagnosis of mantle cell lymphoma (immunohistochemical stain, 25x).

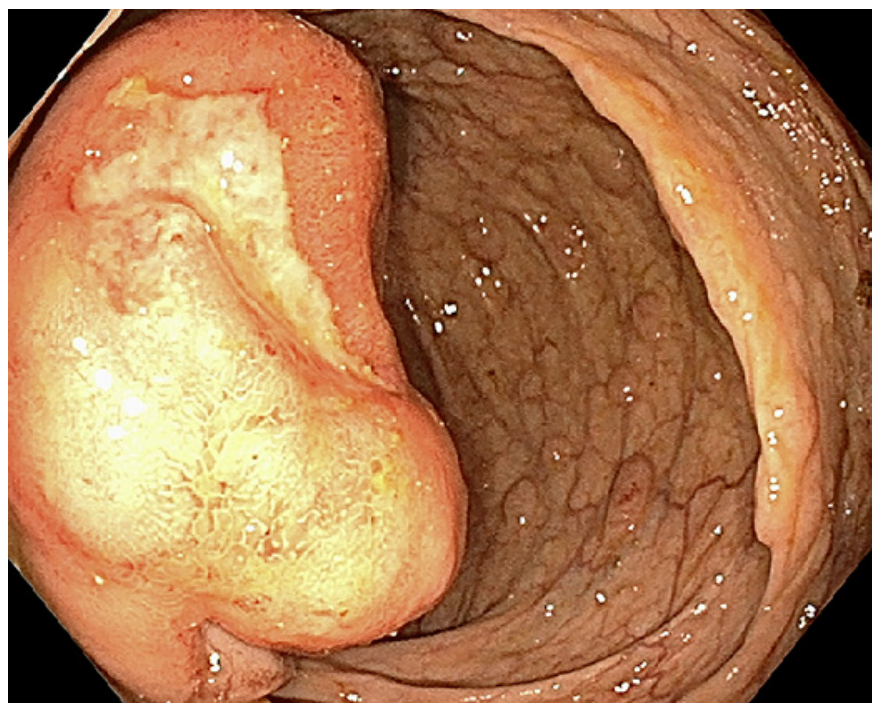

Fig. 2. Ulcerated mass arising from the ileocecal valve.

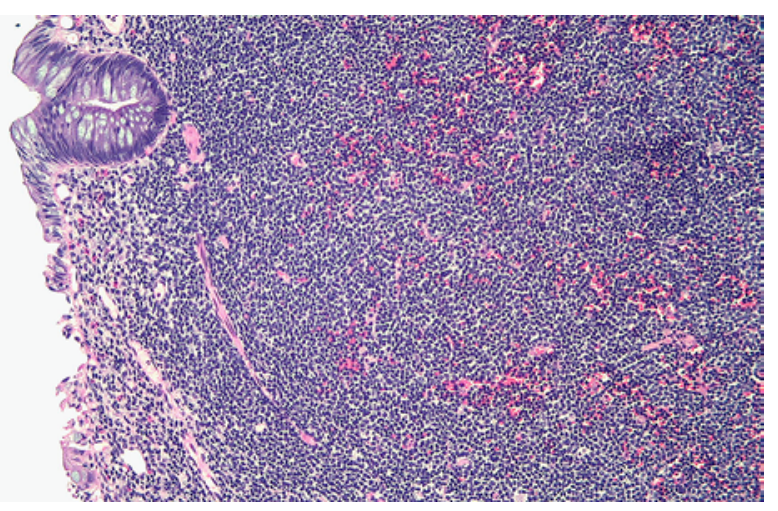

Fig. 4. Mantle cell lymphoma of the colon. Colon mucosa and submucosa with infiltration by neoplastic lymphocytes (H\&E stain, $100 \times)$.

reported in marginal B-cell lymphomas, follicular lymphomas, and mucosa-associated lymphoid tissue (MALT) lymphomas, which makes adequate endoscopic sampling and immunohistochemistry mandatory. There may be a lymphoid mass in the terminal ileum, which may be the initial focus of disease in $35-48 \%$ of cases, although a rectal mass is sometimes described (6\%) [1]. Presenting complaints are most often abdominal pain (65\%), followed by diarrhea (32\%) and hematochezia (22\%). Primary gastrointestinal tract mantle cell lymphoma has a poor prognosis, with a median survival of 3-4 years [3]. Although traditional treatment regimens 
are comprised of R-CHOP [3], recent studies have suggested a role for bendamustine and rituximab [4], particularly if the patient's functional status precludes a more aggressive chemotherapy regimen.

\section{Statement of Ethics}

Consent from the patient was obtained for publication. This paper was conducted ethically in accordance with the Declaration of Helsinki.

\section{Disclosure Statement}

The authors have no conflicts of interest to declare.

\section{Funding Sources}

The authors have no funding sources to declare.

\section{Author Contributions}

All authors made substantial contribution to the conception of the work and the acquisition of data for the work. R.N. drafted the work, contributed to the literature review, and revised it. A.N. drafted the work, contributed to the literature review, performed the endoscopies, and obtained the images. A.A. contributed to the literature review, revised the work, and interpreted the pathological slides. B.S.R. drafted and revised the work and performed the endoscopy. R.S. drafted and revised the work and performed the endoscopy. All authors critically revised the manuscript, approved the final version to be published, and agree to be accountable for all aspects of the work.

\section{References}

1 Ruskoné-Fourmestraux A, Audouin J. Primary gastrointestinal tract mantle cell lymphoma as multiple lymphomatous polyposis. Best Pract Res Clin Gastroenterol. 2010 Feb;24(1): $35-42$.

2 Cheson BD, Fisher RI, Barrington SF, Cavalli F, Schwartz LH, Zucca E, et al.; Alliance, Australasian Leukaemia and Lymphoma Group; Eastern Cooperative Oncology Group; European Mantle Cell Lymphoma Consortium; Italian Lymphoma Foundation; European Organisation for Research; Treatment of Cancer/Dutch Hemato-Oncology Group; Grupo Español de Médula Ósea; German High-Grade Lymphoma
Study Group; German Hodgkin's Study Group; Japanese Lymphorra Study Group; Lymphoma Study Association; NCIC Clinical Trials Group; Nordic Lymphoma Study Group; Southwest Oncology Group; United Kingdom National Cancer Research Institute. Recommendations for initial evaluation, staging, and response assessment of Hodgkin and non-Hodgkin lymphoma: the Lugano classification. J Clin Oncol. 2014 Sep;32(27):3059-68.

3 Lenz G, Dreyling M, Hoster E, Wörmann B, Dührsen U, Metzner B, et al. Immunochemotherapy with rituximab and cyclophosphamide, doxorubicin, vincristine, and predni- sone significantly improves response and time to treatment failure, but not long-term outcome in patients with previously untreated mantle cell lymphoma: results of a prospective randomized trial of the German Low Grade Lymphoma Study Group (GLSG). J Clin Oncol. 2005 Mar;23(9):1984-92.

4 Flinn IW, van der Jagt R, Kahl B, Wood P, Hawkins T, MacDonald D, et al. First-Line Treatment of Patients With Indolent NonHodgkin Lymphoma or Mantle-Cell Lymphoma With Bendamustine Plus Rituximab Versus R-CHOP or R-CVP: Results of the BRIGHT 5-Year Follow-Up Study. J Clin Oncol. 2019 Apr;37(12):984-91. 